\title{
MODEL PENINGKATAN PARTISIPASI PETANI SEKITAR HUTAN DALAM PENGELOLAAN HUTAN KEMIRI RAKYAT: \\ Kasus Pengelolaan Hutan Kemiri Kawasan \\ Pegunungan Bulusaraung Kabupaten Maros \\ Provinsi Sulawesi Selatan \\ (The Model for Increasing Farmers Living Around the Forest \\ Participation in Managing Community Candlenut Forest: Case Study of \\ Candlenut Forest Management on Bulusaraung Mountainrange in Maros \\ District, Soutb Sulawesi Province) ${ }^{1}$
}

\author{
Oleh/By: \\ Adi Riyanto Suprayitno ${ }^{2}$, Sumardjo ${ }^{3}$, Darwis S. Gani ${ }^{4}$, Basita Ginting Sugihen ${ }^{5}$ \\ ${ }^{2}$ Balai Diklat Kehutanan Makassar; HP: 08128760883; email: ars_1221@yahoo.com \\ ${ }^{3,4,5} \mathrm{IPB}$, Kampus Dramaga Bogor
}

\begin{abstract}
Farmers living around the candlenut forest in Maros District have been participating in planting, managing and utilizing that forest since 1826. The existence of candlenut forest, today, is a successful evidence of farmers participation. However, the quality of candlenut forest is declining. That condition cause many bad impacts to environment. This phenomena is presumed that farmers participation is decreasing. This research intended to formulate an effective model to increase farmers participation in managing and utilizing candlenut forest. The data were collected on January-Maret 2010 in Maros District, South Sulawesi Province using some methods: questionnare list, interview, observation, and documents. The data were analyzed using descriptive statistics, and inferensial statistics based on SEM using LISREL 8.70 software programming. The conclusion of the study is the level of farmers participation in managing and utilizing candlenut forest is low. The factors influence farmers participation are farmers motivation and ability. The research proposes an effective model to increase farmers participation in managing and utilizing candlenut forest by increasing four critical aspects. Those critical aspect are: (1) intensity of forestry extention agent roles, (2) farmers ability, (3) farmers motivation, and (4) opportunity forpeople to participate.
\end{abstract}

Keyword: Participation, effective model of participation, community candlenut forest,

\begin{abstract}
ABSTRAK
Petani sekitar hutan kemiri di Kabupaten Maros telah berpartisipasi dalam menanam, mengelola dan memanfaatkan hutan tersebut sejak tahun 1826. Keberadaan hutan kemiri saat ini merupakan bukti keberhasilan partisipasi petani. Namun demikian, pada saat ini hutan kemiri sedang mengalami penurunan kualitas. Kondisi ini berdampak buruk bagi lingkungan sekitarnya. Fenomena ini diduga karena tingkat partisipasi petani menurun. Penelitian ini bertujuan merumuskan model efektif dalam upaya meningkatkan partisipasi petani dalam pengelolaan dan pemanfaatan hutan. Pengumpulan data dilakukan pada Januari sampai Maret 2010, dengan menggunakan metode: kuesioner, wawancara dan observasi, serta dokumen dari instansi terkait. Analisis data menggunakan statistik deskriptif dan statistik inferensial berdasarkan SEM menggunakan piranti lunak LISREL 8.70. Kesimpulan penelitian adalah: tingkat partisipasi petani tergolong rendah. Faktor-faktor yang mempengaruhi partisipasi petani adalah motivasi dan kemampuan petani. Hasil penelitian mengusulkan model efektif peningkatan partisipasi petani dengan meningkakan empat aspek yaitu:
\end{abstract}

\footnotetext{
${ }^{1}$ Sebagian dari disertasi
} 
(1) intensitas peran penyuluh kehutanan, (2) kemampuan petani, (2) motivasi petani, (3) ketersediaan peluang untuk berpartisipasi.

Kata kunci: Partisipasi, model efektif partisipasi, hutan kemiri rakyat,

\section{PENDAHULUAN}

Partisipasi masyarakat dalam pengelolaan hutan penting agar eksistensi hutan dapat terjaga dan dapat merehabilitasi hutan serta meningkatkan kesejahteraan masyarakat. Salah satu strategi yang dilakukan pemerintah adalah mengembangkan hutan rakyat. Hutan kemiri di Kabupaten Maros Sulawesi Selatan yang tumbuh dan tersebar di sepanjang kawasan pegunungan Bantimurung Bulusaraung pada tiga wilayah kecamatan yaitu Kecamatan Cenrana, Kecamatan Camba dan Kecamatan Mallawa sesungguhnya sejak tahun 1826 telah dikelola dan dimanfaatkan oleh petani sekitar kawasan hutan secara turun temurun. Selama berpuluh-puluh tahun dari generasi ke generasi petani sekitar hutan telah mengelola dan memanfaatkan tanaman kemiri sebagai kebun yang pada saat ini secara fisik menampilkan wujud yang setara dengan hutan, bahkan antara tahun 1960-an sampai 1980 Kabupaten Maros dikenal sebagai penghasil kemiri terbesar dengan kualitas terbaik di Indonesia. Pengelolaan dan pemanfaatan hutan kemiri Kabupaten Maros memiliki perbedaan dibandingkan hutan rakyat lain terutama yang berada di Pulau Jawa. Pada hutan kemiri rakyat Kabupaten Maros, pemanfaatannya ditekankan pada upaya memperoleh hasil hutan non kayu yaitu buah kemiri.

Pada saat ini hutan kemiri kawasan pegunungan Bulusaraung mengalami penurunan kualitas yang ditandai dengan rata-rata usia tanaman kemiri sekitar 53 tahun (usia tua/tidak produktif). Penurunan kualitas tersebut secara pasti berpengaruh pada ekologi hutan dan berdampak pula pada menurunnya produktivitas kemiri. Kondisi ini memunculkan pertanyaan mengapa partisipasi petani yang selama ini telah berjalan mengalami degradasi. Tujuan penelitian adalah: (1) menganalisis faktor-faktor penentu peningkatan partisipasi petani sekitar hutan dalam mengelola dan memanfaatkan hutan kemiri Kabupaten Maros, (2) menganalisis dampak partisipasi petani sekitar hutan dalam pengelolaan hutan kemiri terhadap keberlanjutan manfaat/fungsi hutan kemiri Kabupaten Maros, dan (3) merumuskan model efektif dalam upaya meningkatkan partisipasi petani sekitar hutan dalam mengelola dan memanfaatkan hutan kemiri Kabupaten Maros.

\section{METODE PENELITIAN}

\section{A. Lokasi Penelitian}

Paradigma pembangunan kehutanan pada saat ini telah mengalami pergeseran dari pendekatan yang berorientasi pada timber based management ke pendekatan ekosistem yang dikenal dengan resources based management yang bertumpu pada community based development (Pusbinluhhut, 2002). Paradigma baru pembangunan kehutanan menekankan pada pengelolaan hutan berbasis masyarakat, di mana partisipasi aktif masyarakat sangat diperlukan dalam mengelola dan menjaga eksistensi hutan. Pendekatan ini telah menempatkan masyarakat sebagai bagian dari pelaku utama pengelolaan hutan.

Model Peningkatan Partisipasi Petani Sekitar Hutan dalam Pengelolaan ...... (Adi Riyanto Suprayitno et al.) 
Pergeseran paradigma tersebut mendorong perlunya tranformasi/perubahan atau perbaikan terhadap beberapa aspek dari kondisi yang dianggap belum ideal ke kondisi yang ideal, sebagaimana ditampilkan pada Tabel 1. Perubahan tersebut diharapkan dapat mempengaruhi kualitas partisipasi masyarakat.

Tabel 1. Transformasi beberapa aspek menuju pengelolaan hutan yang partisipatif Table 1. Transforming some aspects to participatory forest management

\begin{tabular}{|c|c|c|c|}
\hline No & Aspek & Kondisi belum ideal & Kondisi ideal \\
\hline 1 & $\begin{array}{l}\text { Pengalaman masyarakat } \\
\text { dalam mengelola hutan }\end{array}$ & Belum berpengalaman & Berpengalaman \\
\hline 2 & $\begin{array}{l}\text { Ketergantungan petani } \\
\text { terhadap hutan }\end{array}$ & Non adaptif & Adaptif \\
\hline 3 & Kearifan lokal & $\begin{array}{l}\text { Tidak mendukung } \\
\text { kelestarian hutan }\end{array}$ & $\begin{array}{l}\text { Mendukung kelestarian } \\
\text { hutan }\end{array}$ \\
\hline 4 & Tokoh masyarakat & Apatis & Mendorong masyarakat \\
\hline 5 & Peran penyuluh kehutanan & linear & Konvergen/partisipatif \\
\hline 6 & Peran pemerintah & Dominan & Mitra (kolaborator) \\
\hline 7 & Mekanisme pasar & Monopsoni & Kompetitif \\
\hline 8 & $\begin{array}{l}\text { Motivasi masyarakat } \\
\text { mengelola hutan }\end{array}$ & $\begin{array}{l}\text { Belum berorientasi } \\
\text { pada kelestarian hutan }\end{array}$ & $\begin{array}{l}\text { Berorientasi pada } \\
\text { kelestarian hutan }\end{array}$ \\
\hline 9 & Kemampuan petani & Tidak terlatih & Terlatih \\
\hline 10 & Partisipasi petani & Parsial & Menyeluruh \\
\hline
\end{tabular}

Partisipasi yang ideal terjadi apabila masyarakat terlibat secara penuh mulai dari perencanaan, pelaksanaan kegiatan, pemanfaatan hasil kegiatan dan pengawasan serta penilaian kegiatan.

Partisipasi petani sekitar hutan kemiri Kabupaten Maros dalam mengelola hutan kemiri dapat menjadi dukungan yang sangat berarti bagi terpeliharanya hutan tersebut. Partisipasi petani sekitar hutan kemiri, pada awalnya, merupakan partisipasi swakarsa karena inisiatif pembentukan dan pengelolaannya berasal dari dalam masyarakat petani tersebut. Penurunan kualitas hutan kemiri, saat ini, merupakan indikasi bahwa sedang terjadi degradasi partisipasi petani. Petani yang sebelumnya aktif terlibat dalam kegiatan pengelolaan dan pemanfaatan hutan, pada saat ini tidak lagi memperhatikan keberlanjutan tanaman kemiri.

Penurunan tingkat partisipasi petani sekitar hutan dalam pengelolaan hutan kemiri dapat disebabkan oleh berbagai faktor/aspek sebagaimana Tabel 1. Aspek-aspek tersebut kemudian dituangkan pada Gambar 1 yang menjadi acuan penelitian untuk merumuskan model peningkatan partisipasi petani sekitar hutan dalam pengelolaan hutan kemiri rakyat.

Menurut Slamet (2003), agar tumbuh partisipasi, paling tidak ada tiga syarat yang harus dipenuhi, yaitu adanya kesempatan dalam pembangunan, adanya kemampuan untuk memanfaatkan kesempatan tersebut, dan adanya kemauan/motivasi untuk berpartisipasi. Slamet (2003) menyatakan bahwa masyarakat tidak dapat merubah kualitas hidupnya dan pembangunan tidak akan tercapai apabila masyarakat tidak tergerak untuk memanfaatkan kesempatan yang ada. Suatu pekerjaan, termasuk partisipasi, membutuhkan adanya kemampuan bagi pelaksana pekerjaan tersebut sebagaimana dinyatakan Robin (2003) bahwa kemampuan merupakan kapasitas individu untuk mengerjakan berbagai tugas dalam suatu pekerjaan. 
Motivasi mempersoalkan bagaimana individu terdorong untuk mau bekerja keras dengan memberikan semua kemampuan dan keterampilannya untuk mewujudkan tujuan hidupnya demikian dikemukakan oleh Hasibuan (1999). Individu yang mempunyai motivasi akan bersedia mencurahkan energi fisik dan mentalnya untuk melakukan pekerjaan. Bila dikaitkan dengan pengelolaan hutan secara lestari maka motivasi petani untuk terlibat dalam pengelolaan hutan merupakan hal yang penting karena dengan adanya motivasi diharapkan setiap petani sekitar hutan mau berpartisipasi dalam arti mau bekerja keras dan antusias untuk mengelola hutan sehingga tercapai produktivitas yang tinggi dengan mengedepankan kelestarian hutan.

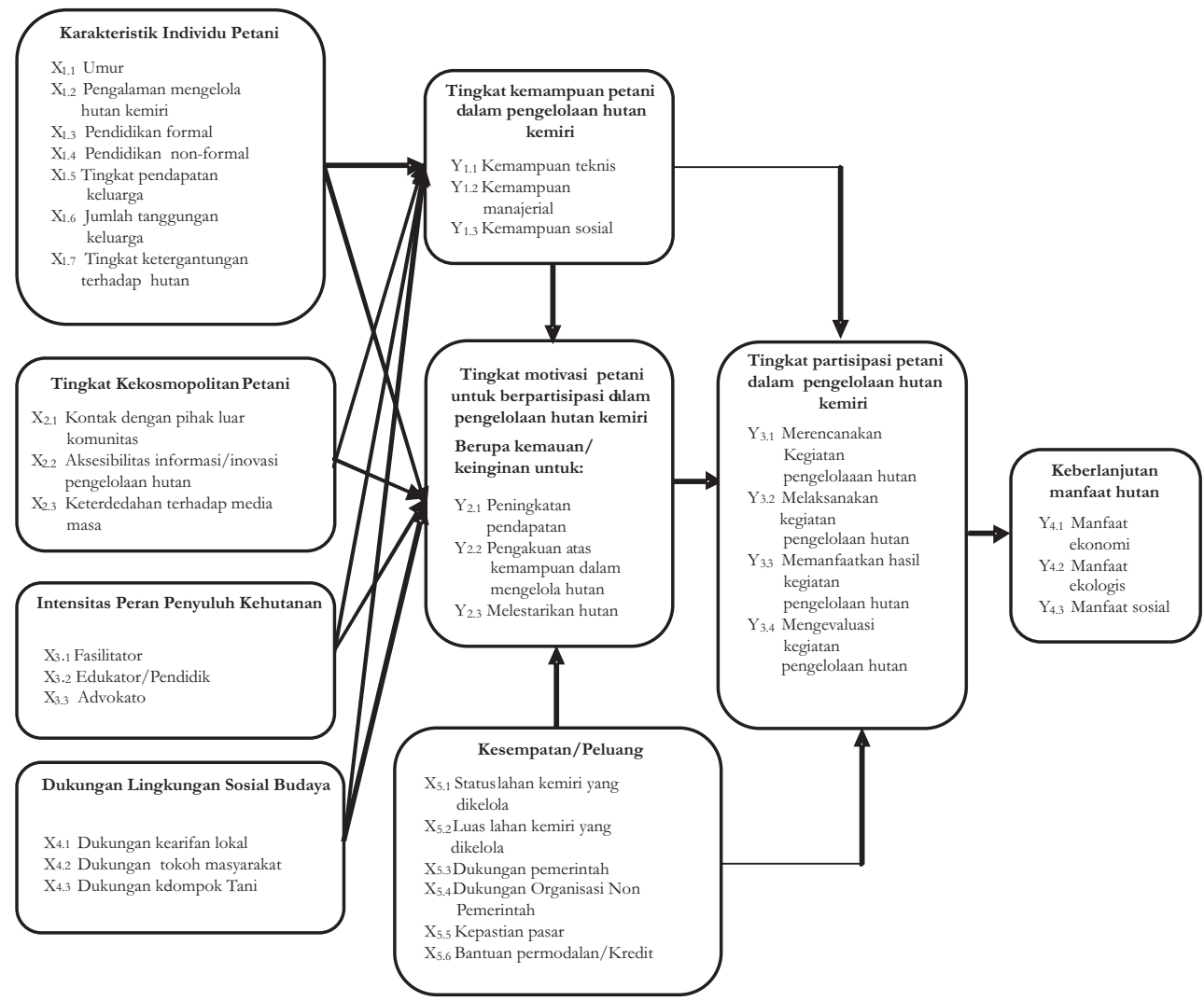

Gambar 1. Kerangka berpikir penelitian

Figure 1. Research framework.

Desain penelitian yang digunakan adalah ex post facto atau sering disebut sebagai penelitian causal-comparatif. Desain penelitian ex post facto digunakan untuk menjajagi kemungkinan hubungan kausalitas (sebab-akibat) di antara peubah bebas dan peubah terikat tanpa adanya manipulasi atau perlakuan dari peneliti terhadap peubah terikat (Kountor, 2006; Hadjar, 1996; Sevilla et.al., 1993). Desain ex post facto menfokuskan penyelidikan pada apa yang sebenarnya telah terjadi. Pemilihan lokasi dilakukan secara purposive dengan pertimbangan bahwa hutan kemiri kawasan pegunungan Bulusaraung merupakan areal hutan

Model Peningkatan Partisipasi Petani Sekitar Hutan dalam Pengelolaan ...... (Adi Riyanto Suprayitno et al.) 
kemiri terluas di Sulawesi Selatan. Penelitian dilakukan di desa-desa yang berada di sekitar hutan kemiri kawasan pegunungan Bulusaraung di tiga kecamatan di kabupaten Maros Provinsi Sulawesi Selatan. Sebagai populasi penelitian adalah rumah tangga petani yang memiliki dan/atau menggarap lahan hutan kemiri. Teknik pengambilan sampel adalah proporsionate random sampling berdasarkan luasan hutan di setiap kecamatan, dengan jumlah sampel sebanyak 204 kepala rumah tangga. Pengumpulan data primer dilakukan dengan cara pengisisan kuesioner dan wawancara terstruktur serta observasi langsung. Data sekunder diperoleh dari berbagai kantor/instansi terkait. Pengolahan dan analisa data menggunakan statistik deskriptif, dan statistik inferensial (SEM dengan menggunakan software LISREL 8.70).

\section{HASIL DAN PEMBAHASAN}

\section{A. Deskripsi Variabel Penelitian}

\section{Karakteristik individu}

Gambaran karakteristik individu yang diamati (Tabel 2) memperlihatkan rata-rata usia responden sekitar 48,6 tahun, rata-rata pengalaman responden mengelola hutan kemiri sekitar 28,2 tahun, lamanya pendidikan formal responden sekitar 7,5 tahun (setara dengan SMP kelas VII atau tidak lulus SMP). Pendidikan non formal responden rendah, sebagian besar responden (96\%) tidak pernah mengikuti pendidikan non formal. Pendapatan responden perbulan sebesar Rp 945.804. Jumlah tanggungan keluarga berkisar 4 orang dan tingkat kebergantungan respoden terhadap sumberdaya hutan adalah rendah.

Tabel 2. Deskripsi variabel penelitian

Table 2. Description of research variables

\begin{tabular}{|l|c|c|c|c|}
\hline \multirow{2}{*}{\multicolumn{1}{c|}{ VARIABEL/INDIKATOR }} & \multicolumn{4}{|c|}{ Rataan (Mean) } \\
\cline { 2 - 5 } & $\begin{array}{c}\text { Kecamatan } \\
\text { Cenrana }\end{array}$ & $\begin{array}{c}\text { Kecamatan } \\
\text { Camba }\end{array}$ & $\begin{array}{c}\text { Kecamatan } \\
\text { Mallawa }\end{array}$ & Total \\
\hline KARAKTERISTIK INDIVIDU & 49,6 & 50,5 & 47,1 & 48,6 \\
Umur (Tahun) & 29,3 & 21,7 & 30,8 & 28,2 \\
Pengalaman (Tahun) & 6,1 & 8,7 & 7,7 & 7,5 \\
Pendidikan Formal (Tahun) & 1,9 & 0,4 & 0,1 & 0,6 \\
Pendidikan non Formal (Jpl) & 1.307 .881 & 882.693 & 781.838 & 945.804 \\
Pendapatan/bulan (Rupiah) & 4,1 & 3,6 & 4,5 & 4,2 \\
Tanggungan keluarga (Jiwa) & 38,9 & 22,0 & 23,2 & 27,0 \\
Kebergantungan terhadap SDH (Skor) & \multicolumn{3}{|c}{} \\
\hline
\end{tabular}

\section{Tingkat kekosmopolitan petani}

Tingkat kekosmopolitan petani tergolong rendah. Terlihat bahwa semua aspek dari tingkat kekosmopolitan tergolong rendah (Tabel 3). Rendahnya tingkat kekosmopolitan merupakan dampak dari terbatasnya akses untuk mengelola dan meremajakan tanaman kemiri. 
Tabel 3. Tingkat kekosmopolitan petani

Table 3. Farmers' cosmopolite level

\begin{tabular}{|l|c|c|c|c|}
\hline \multirow{2}{*}{ VARIABEL/INDIKATOR } & \multicolumn{4}{|c|}{ Rataan (Mean) } \\
\cline { 2 - 5 } & $\begin{array}{c}\text { Kecamatan } \\
\text { Cenrana }\end{array}$ & $\begin{array}{c}\text { Kecamatan } \\
\text { Camba }\end{array}$ & $\begin{array}{c}\text { Kecamatan } \\
\text { Mallawa }\end{array}$ & Total \\
\hline TINGKAT KEKOSMOPOLITAN & & & & \\
PETANI & 0,04 & 0,1 & 0,5 & 0,3 \\
Kontak(frekuensi) & 5,6 & 1,7 & 2,0 & 2,9 \\
Aksesibilitas thd informasi (Skor) & 0,1 & 0,0 & 0,0 & 0,03 \\
Keterdedehan thd media (jam/minggu) &
\end{tabular}

Ket: Kontak; Rendah $=$ tidak pernah, Sedang $=1$ kali/bulan, Tinggi $=>2$ kali/bulan Aksesibilitas Informasi: Rendah $=$ skor $0-50$, Sedang $=$ skor $51-75$, Tinggi $=$ skor 76-100

Keterdedahan thd media massa; Rendah $=$ tidak pernah, Sedang $=1-2 \mathrm{jam} / \mathrm{minggu}$ Tinggi $=$ $3 \mathrm{jam} /$ minggu

\section{Intensitas peran penyuluh kehutanan}

Intensitas peran penyuluh kehutanan tergolong rendah. Hal ini terlihat dari rendahnya aspek-aspek dari variabel tersebut (Tabel 4).

Tabel 4. Intensitas peran penyuluh kehutanan

Table 4. Intensity of forestry extension role

\begin{tabular}{|l|c|c|c|c|}
\hline \multirow{2}{*}{ VARIABEL/INDIKATOR } & \multicolumn{4}{|c|}{ Rataan (Mean $)$} \\
\cline { 2 - 5 } & $\begin{array}{c}\text { Kecamatan } \\
\text { Cenrana }\end{array}$ & $\begin{array}{c}\text { Kecamatan } \\
\text { Camba }\end{array}$ & $\begin{array}{c}\text { Kecamatan } \\
\text { Mallawa }\end{array}$ & Total \\
\hline INTENSITAS PERAN PENYULUH & & & & \\
KEHUTANAN & 47,2 & 38,2 & 41,4 & 42,2 \\
Peran Fasilitator (Skor) & 51,4 & 39,0 & 40,6 & 43,1 \\
Peran Pendidik (Skor) & 13,9 & 26,8 & 39,0 & 29,4 \\
Peran Advokator (Skor) &
\end{tabular}

Ket: Rendah $=$ skor $0-50$, Sedang $=$ skor $51-75$, Tinggi $=$ skor $76-100$

\section{Dukungan lingkungan sosial budaya}

Dukungan lingkungan sosial budaya (Tabel 5) pada aspek dukungan tokoh masyarakat dan kelompok tani tergolong rendah, kecuali dukungan kearifan lokal yang masuk dalam kategori sedang.

Tabel 5. Dukungan lingkungan sosial budaya

Table 5. Social cultural environment supporting

\begin{tabular}{|l|c|c|c|c|}
\hline \multirow{2}{*}{ VARIABEL/INDIKATOR } & \multicolumn{4}{|c|}{ Rataan (Mean } \\
\cline { 2 - 5 } & $\begin{array}{c}\text { Kecamatan } \\
\text { Cenrana }\end{array}$ & $\begin{array}{c}\text { Kecamatan } \\
\text { Camba }\end{array}$ & $\begin{array}{c}\text { Kecamatan } \\
\text { Mallawa }\end{array}$ & Total \\
\hline DUKUNGAN LINGKUNGAN & & & & \\
SOSIAL BUDAYA & 56,2 & 59,0 & 56,5 & 57,0 \\
Kearifan lokal (Skor) & 36,4 & 29,7 & 33,1 & 33,1 \\
Tokoh masyarakat (Skor) & 18,1 & 24,0 & 15,2 & 18,1 \\
Kelompok tani (Skor) &
\end{tabular}

Ket: Rendah $=$ skor $0-50$, Sedang $=$ skor $51-75$, Tinggi $=$ skor $76-100$

Model Peningkatan Partisipasi Petani Sekitar Hutan dalam Pengelolaan ...... (Adi Riyanto Suprayitno et al.) 


\section{Kesempatan/peluang}

Ketersediaan peluang juga tergolong rendah, yang ditandai dengan rendahnya sebagian besar aspek (Tabel 6), juga karena sebagian besar (85\%) status kepemilikan lahan adalah kawasan hutan dengan luas lahan yang dimanfaatkan adalah 2,1 ha (kombinasi antara milik sendiri, kawasan hutan dan tanah negara), kecuali aspek kepastian pasar yang tergolong sedang. Petani tidak menemukan kesulitan dalam pemasaran kemiri karena telah ada pihak yang siap menampung atau membeli biji kemiri. Namun demikian, dalam jaringan transaksi jual beli kemiri, petani memiliki posisi tawar yang lebih rendah.

Tabel 6. Kesempatan/peluang

Table 6. Opportunity

\begin{tabular}{|l|c|c|c|c|}
\hline \multirow{2}{*}{\multicolumn{1}{c|}{ VARIABEL/INDIKATOR }} & \multicolumn{4}{|c|}{ Rataan (Mean) } \\
\cline { 2 - 5 } & $\begin{array}{c}\text { Kecamatan } \\
\text { Cenrana }\end{array}$ & $\begin{array}{c}\text { Kecamatan } \\
\text { Camba }\end{array}$ & $\begin{array}{c}\text { Kecamatan } \\
\text { Mallawa }\end{array}$ & Total \\
\hline KESEMPATAN/PELUANG & 1,4 & 2,3 & 2,4 & 2,1 \\
Luas lahan (Ha) & 34,6 & 33,2 & 28,1 & 31,1 \\
Dukungan Pemerintah (Skor) & 2,5 & 3,0 & 4,8 & 3,8 \\
Dukungan non pemerintah (Skor) & 61,9 & 72,2 & 61,8 & 64,4 \\
Kepastian pasar (Skor) & 1,2 & 10,7 & 1,3 & 3,6 \\
Bantuan permodalan/kredit (Skor) & & & & \\
\hline
\end{tabular}

Ket: Rendah $=$ skor $0-50$, Sedang $=$ skor $51-75$, Tinggi $=$ skor $76-100$

\section{Tingkat kemampuan petani}

Tingkat kemampuan petani sekitar hutan dalam mengelola hutan kemiri tergolong sedang. Terlihat bahwa sebagian besar aspek dari tingkat kemampuan petani masuk dalam kategori sedang. Tingkat kemampuan petani diperoleh melalui proses alih pengetahuan yang berlangsung secara turun temurun. Petani telah memiliki kemampuan yang cukup memadai untuk mengelola hutan kemiri walaupun dilakukan secara sederhana.

Tabel 7. Tingkat kemampuan petani

Table 7. Farmer's abilities level

\begin{tabular}{|c|c|c|c|c|}
\hline \multirow[b]{2}{*}{ VARIABEL/INDIKATOR } & \multicolumn{4}{|c|}{ Rataan $($ Mean $)$} \\
\hline & $\begin{array}{c}\text { Kecamatan } \\
\text { Cenrana }\end{array}$ & $\begin{array}{c}\text { Kecamatan } \\
\text { Camba }\end{array}$ & $\begin{array}{c}\text { Kecamatan } \\
\text { Mallawa }\end{array}$ & Total \\
\hline TINGKAT KEMAMPUAN PETANI & & & & \\
\hline Kemampuan teknis (Skor) & 57,9 & 58,7 & 55,1 & 56,7 \\
\hline Kemampuan manajerial (Skor) & 53,4 & 49,1 & 41,2 & 46,3 \\
\hline Kemampuan sosial (Skor) & 67,2 & 67,6 & 68,5 & 67,9 \\
\hline
\end{tabular}

Ket: Rendah $=$ skor $0-50$, Sedang $=$ skor $51-75$, Tinggi $=$ skor $76-100$

\section{Tingkat motivasi petani}

Tingkat motivasi petani sekitar hutan untuk berpartisipasi tergolong sedang, baik dari aspek motivasi meningkatkan pendapatan, motivasi untuk mendapat pengakuan, dan motivasi melestarikan hutan. Hal ini berarti motivasi petani untuk berpartisipasi merupakan potensi internal petani yang dapat melahirkan keberhasilan pengelolaan hutan kemiri. Motivasi petani untuk berpartisipasi didasari oleh sejarah panjang kesuksesan pengelolaan hutan kemiri yang sudah dilakukan secara turun temurun. 
Tabel 8. Tingkat motivasi petani

Table 8. Farmer's motivation level

\begin{tabular}{|l|c|c|c|c|}
\hline \multirow{2}{*}{ VARIABEL/INDIKATOR } & \multicolumn{4}{|c|}{ Rataan (Mean) } \\
\cline { 2 - 5 } & $\begin{array}{c}\text { Kecamatan } \\
\text { Cenrana }\end{array}$ & $\begin{array}{c}\text { Kecamatan } \\
\text { Camba }\end{array}$ & $\begin{array}{c}\text { Kecamatan } \\
\text { Mallawa }\end{array}$ & Total \\
\hline TINGKAT MOTIVASI PETANI & & & & \\
UNTUK BERPARTISIPASI & 53,5 & 58,9 & 46,0 & 51,1 \\
Meningkatkan pendapatan (Skor) & 60,8 & 78,3 & 66,8 & 68,1 \\
Mendapat pengakuan atas kemampuan & 61,9 & 77,2 & 73,3 & 71,2 \\
(Skor) & & & \\
Melestarikan hutan (skor)
\end{tabular}

Ket: Rendah $=$ skor $0-50$, Sedang $=$ skor $51-75$, Tinggi $=$ skor $76-100$

\section{Tingkat partisipasi petani}

Tingkat partisipasi petani sekitar hutan dalam pengelolaan hutan kemiri tergolong rendah, yang ditunjukkan oleh rendahnya semua tahapan partisipasi yaitu partisipasi dalam merencanakan kegiatan pengelolaan hutan dengan rataan skor 5,8, partisipasi dalam melaksanakan kegiatan pengelolaan hutan dengan rataan skor 39,7, partisipasi dalam memanfaatkan atau menikmati hasil kegiatan pengelolaan hutan dengan rataan skor 29,8 dan partisipasi dalam mengawasi dan menilai kegiatan pengelolaan hutan dengan rataan skor 11,4 (Tabel 9).

Tabel 9. Tingkat partisipasi petani Table 9. Farmer'sparticipation level

\begin{tabular}{|l|c|c|c|c|}
\hline \multirow{2}{*}{ VARIABEL/INDIKATOR } & \multicolumn{4}{|c|}{ Rataan (Mean) } \\
\cline { 2 - 5 } & $\begin{array}{c}\text { Kecamatan } \\
\text { Cenrana }\end{array}$ & $\begin{array}{c}\text { Kecamatan } \\
\text { Camba }\end{array}$ & $\begin{array}{c}\text { Kecamatan } \\
\text { Mallawa }\end{array}$ & Total \\
\hline TINGKAT PARTISIPASI PETANI & 17,2 & 3,7 & 0,7 & 5,8 \\
Perencanaan (Skor) & 32,3 & 42,5 & 42,2 & 39,7 \\
Pelaksanaan kegiatan (Skor) & 29,9 & 27,7 & 30,7 & 29,8 \\
Menikmati/memanfaatkani hasil (Skor) & 9,9 & 14,1 & 10,9 & 11,4 \\
Pengawasan dan penilaian (Skor) &
\end{tabular}

Ket; Rendah $=$ skor $0-50$, Sedang $=$ skor $51-75$, Tinggi $=$ skor $76-100$

\section{Keberlanjutan manfaat hutan}

Keberlanjutan manfaat hutan kemiri, juga, dirasakan rendah oleh responden. Hal ini terjadi karena produktivitas tanaman kemiri sudah sangat menurun sebagai akibat tidak idealnya komposisi tegakan yaitu $79 \%$ tegakan yang ada berusia tua (> 35 tahun) sehingga walaupun masih dirasakan manfaatnya namun terasa rendah kontribusinya bagi pendapatan rumah tangga petani. Hal ini juga berdampak pada rendahnya manfaat ekologis yang dirasakan petani karena tidak idealnya komposisi tegakan secara langsung mempengaruhi kondisi ekologis hutan. Manfaat sosial hutan kemiri juga dirasakan rendah oleh petani. Penetapan Tata Guna Hutan Kesepakatan (TGHK) pada tahun 1984 berdampak pada manfaat sosial hutan tersebut. Keterbatasan akses petani mengakibatkan hutan tidak mampu lagi memberikan lapangan kerja bagi petani sekitar hutan, sehingga sebagian generasi muda merantau ke daerah lain untuk berkebun seperti ke Sulawesi Tenggara, Sulawesi Tengah, dan sebagian menjadi TKI di Malaysia dan Arab Saudi.

Model Peningkatan Partisipasi Petani Sekitar Hutan dalam Pengelolaan ...... (Adi Riyanto Suprayitno et al.) 
Tabel 10. Keberlanjutan manfaat hutan

Table 10. Forest function sustainability

\begin{tabular}{|l|c|c|c|c|}
\hline \multirow{2}{*}{ VARIABEL/INDIKATOR } & \multicolumn{4}{|c|}{ Rataan (Mean $)$} \\
\cline { 2 - 5 } & $\begin{array}{c}\text { Kecamatan } \\
\text { Cenrana }\end{array}$ & $\begin{array}{c}\text { Kecamatan } \\
\text { Camba }\end{array}$ & $\begin{array}{c}\text { Kecamatan } \\
\text { Mallawa }\end{array}$ & Total \\
\hline KEBERLANJUTAN MANFAAT HUTAN & & & & \\
Manfaat ekonomi (Skor) & 20,4 & 15,5 & 24,1 & 21,0 \\
Manfaat ekologi (Skor) & 45,4 & 36,8 & 54,0 & 47,5 \\
Manfaat sosial (Skor) & 37,3 & 21,3 & 40,2 & 34,8 \\
\hline
\end{tabular}

Kategori; Rendah $=$ skor $0-50$, Sedang $=$ skor $51-75$, Tinggi $=$ skor $76-100$

\section{Analisa Faktor-Faktor yang Mempengaruhi Tingkat Partisipasi Petani Sekitar Hutan dalam Pengelolaan Hutan Kemiri Rakyat}

Analisis terhadap faktor-faktor penentu tingkat partisipasi petani sekitar hutan dalam pengelolaan hutan kemiri rakyat dilakukan dengan menggunakan SEM dengan bantuan program LISREL 8.70, memperoleh hasil akhir model struktural dalam bentuk diagram lintasan sebagaimana Gambar 2.

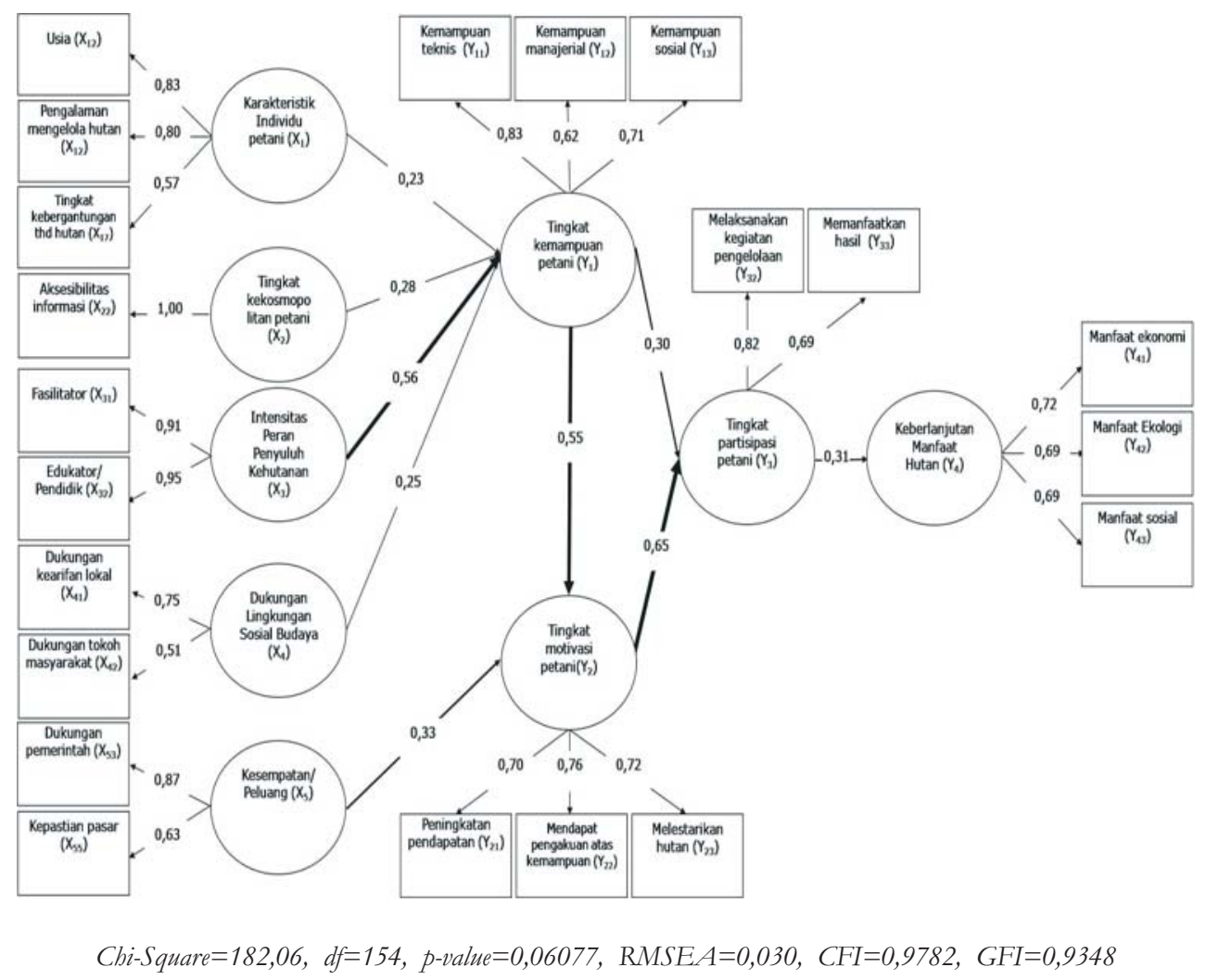

Gambar 2. Model struktural

Figure 2. Structural modelling 


\section{B. Faktor-Faktor yang Mempengaruhi Tingkat Partisipasi Petani Sekitar Hutan Kemiri dalam Pengelolaan Hutan Kemiri}

Faktor-faktor yang mempengaruhi tingkat partisipasi petani untuk mengelola hutan kemiri adalah:

1. tingkat motivasi petani; dan

2. tingkat kemampuan petani, dengan persamaan struktural: $\mathrm{Y}_{3}=0,30 \mathrm{Y}_{1}+0,65 \mathrm{Y}_{2}, \mathrm{R}^{2}=0,78$. Besarnya kontribusi kedua faktor tersebut secara bersama-sama terhadap tingkat kemampuan petani dalam mengelola hutan kemiri rakyat adalah sebesar 78\%.

\section{Motivasi petani untuk berpartisipasi}

Tingkat motivasi untuk berpartisipasi memiliki pengaruh terbesar terhadap tingkat partisipasi petani dalam pengelolaan hutan kemiri, di mana aspek yang dominan berpengaruh terhadap tingkat partisipasi petani dalam mengelola hutan kemiri adalah motivasi untuk mendapatkan pengakuan atas kemampuan dalam mengelola hutan kemiri. Hal ini dapat dimaklumi karena petani sekitar hutan kemiri, pada umumnya, telah melakukan praktek pengelolaan hutan kemiri, dengan demikian telah terbentuk dan menyatu dalam diri mereka kemampuan praktis dalam mengelola hutan kemiri.

Aspek kedua yang memiliki pengaruh terhadap tingkat partisipasi petani dalam mengelola hutan kemiri adalah motivasi untuk melestarikan hutan kemiri. Motivasi melestarikan hutan kemiri ini disebabkan secara psikologis petani sekitar hutan memiliki ikatan emosional, historis, dan sosial dengan keberadaan hutan kemiri. Selain itu, disebabkan pula oleh adanya kebiasaan petani di Sulawesi selatan yaitu memberikan/meninggalkan warisan berupa lahan sebagai jaminan atau rasa aman bagi kehidupan masa depan anak cucunya. Kebiasaan tersebut sejalan dengan pernyataan Awang (2003) bahwa bagi masyarakat lokal, hutan dianggap sebagai cadangan lahan untuk keturunan dan masa depan keluaga, dan masyarakat.

Aspek berikutnya yang berpotensi memiliki pengaruh terhadap tingkat partisipasi petani dalam mengelola hutan kemiri adalah motivasi untuk meningkatkan pendapatan. Walaupun hasil hutan kemiri kontribusinya kecil terhadap total pendapatan rumah tangga, namun petani tetap berminat untuk mengelola dan memanfaatkannya karena hutan kemiri dijadikan sebagai salah satu sumber pendapatan rumah tangga yaitu sebagai tabungan atau cadangan dana yang dapat dijual sewaktu-waktu jika petani membutuhkan uang.

\section{Tingkat kemampuan petani}

Tingkat kemampuan petani dalam mengelola hutan kemiri merupakan faktor kedua yang berpotensi mempengaruhi tingkat partisipasi petani dalam pengelolaan hutan kemiri, di mana aspek yang memiliki pengaruh paling dominan adalah kemampuan teknis. Petani sekitar hutan kemiri pada dasarnya telah memiliki kemampuan teknis pengelolaan hutan kemiri yang memadai kemiri yang diperoleh secara turun temurun sehingga yakin bahwa mereka mampu untuk tetap mengelola hutan kemiri.

Kemampuan sosial merupakan aspek kedua yang berpotensi mempengaruhi tingkat partisipasi petani dalam pengelolaan hutan kemiri. Kemampuan sosial yang dimiliki petani telah memampukan petani untuk mengatasi dan menyelesaikan masalah atau konflik yang timbul dalam pengelolaan hutan sehingga terjalin keharmonisan, terbukti bahwa sejak lama

Model Peningkatan Partisipasi Petani Sekitar Hutan dalam Pengelolaan ...... (Adi Riyanto Suprayitno et al.) 
petani telah membangun interaksi dan kerjasama di antara mereka serta pihak lain dalam kegiatan pengelolaan hutan kemiri, sehingga pengelolaan hutan kemiri berjalan dengan baik.

Aspek kemampuan berikutnya yang berpotensi mempengaruhi tingkat partisipasi petani dalam pengelolaan hutan kemiri adalah kemampuan manajerial. Walaupun tampilan kemampuan manajerial terlihat rendah, namun secara prinsip petani sekitar hutan kemiri telah melakukan kegiatan manajemen yaitu perencanaan, pengaturan, pendayagunaan tenaga kerja, pengawasan dan pengevaluasian atas usahatani yang dijalankannya dengan mengandalkan pada kebiasaan, pengetahuan dan kearifan lokal, dengan kata lain masih bersifat sederhana atau apa adanya, tidak berdasarkan manajemen modern.

\section{Faktor-Faktor yang Mempengaruhi Tingkat Kemampuan Petani Sekitar Hutan Kemiri}

Faktor-faktor yang mempengaruhi tingkat kemampuan petani dalam pengelolaan hutan kemiri adalah:

1. intensitas peran penyuluh kehutanan;

2. tingkat kekosmopolitan petani;

3. dukungan lingkungan sosial budaya; dan

4. karakteristik individu petani

dengan persamaan struktural: $Y_{1}=0,23 X_{1}+0,28 X_{2}+0,56 X_{3}+0,25 X_{4}, R^{2}=0,79$. Besarnya kontribusi keempat faktor tersebut secara bersama-sama terhadap tingkat kemampuan petani dalam mengelola hutan kemiri rakyat adalah sebesar $79 \%$.

\section{Intensitas peran penyuluh kehutanan}

Intensitas peran penyuluh kehutanan memberikan pengaruh paling kuat terhadap tingkat kemampuan petani sekitar hutan dalam mengelola hutan kemiri, di mana intensitas peran sebagai pendidik berpotensi paling besar untuk meningkatkan kemampuan petani sehingga dapat mengelola hutan kemiri dengan baik. Temuan ini sejalan dengan pendapat Sudjana (2000) bahwa pendidikan merupakan usaha yang bertujuan mengembangkan potensi, membudayakan, dan memanusiakan manusia. Peran sebagai pendidik dilakukan oleh penyuluh melalui proses belajar mengajar yang didalamnya terjadi proses alih dan saling berbagi pengetahuan, yang berimplikasi pada terjadinya perubahan atau peningkatan kemampuan petani.

Intensitas peran berikutnya yang berpotensi meningkatkan kemampuan petani sekitar hutan kemiri dalam mengelola hutan kemiri adalah intensitas peran sebagai fasilitator, di mana penyuluh kehutanan merangsang, mendorong, membangkitkan semangat, membantu dan memudahkan petani sekitar hutan dalam proses pembelajaran sosial, sehingga kemampuan mereka dapat meningkat yang selanjutnya dapat digunakan untuk pengambilan keputusan yang tepat dalam pengelolaan hutan kemiri, sebagaimana dikemukakan oleh Van Den Ban dan Hawkins (1999) bahwa penyuluh berperan membantu petani agar mampu menemukan sendiri pemecahan masalah dan mampu mengambil keputusan sendiri terkait dengan usahataninya.

\section{Tingkat kekosmopolitan petani}

Tingkat kekosmopolitan petani yang direfleksikan oleh aksesibilitas petani terhadap informasi pengelolaan hutan kemiri merupakan faktor kedua yang berpengaruh terhadap 
tingkat kemampuan petani sekitar hutan dalam pengelolaan hutan kemiri. Semakin luas akses petani terhadap berbagai informasi pengelolaan hutan kemiri, maka akan semakin meningkat kemampuannya dalam mengelola hutan kemiri. Petani yang memiliki akses luas terhadap berbagai sumber informasi akan memiliki informasi yang lebih banyak, implikasinya pengetahuan dan wawasan mereka lebih luas, sikap mereka akan lebih baik, dan keterampilan mereka akan bertambah baik.

\section{Dukungan lingkungan sosial budaya}

Dukungan lingkungan sosial budaya merupakan faktor ketiga yang berpengaruh terhadap tingkat kemampuan petani sekitar hutan dalam mengelola hutan kemiri, di mana dukungan kearifan lokal memiliki pengaruh paling dominan terhadap tingkat kemampuan petani sekitar hutan dalam mengelola hutan kemiri. Nilai-nilai kearifan yang dianut petani sekitar hutan kemiri telah menciptakan praktek pengelolaan hutan kemiri yang baik. Aspek berikutnya yang berpotensi mempengaruhi tingkat kemampuan petani dalam mengelola hutan kemiri adalah dukungan tokoh masyarakat. Hal ini berarti tokoh masyarakat sekitar hutan kemiri dapat memainkan peranan penting dalam memotivasi masyarakat atau petani sekitar hutan untuk melestarikan hutan. Temuan ini sejalan dengan pendapat Rogers dan Shoemaker (Hanafie, 1986) bahwa tokoh masyarakat memainkan peranan penting dalam mempengaruhi perilaku orang lain.

\section{Karakteristik individu petani}

Karakteristik individu petani merupakan faktor keempat yang berpengaruh terhadap tingkat kemampuan petani sekitar hutan dalam mengelola hutan kemiri. Aspek umur memiliki pengaruh paling dominan terhadap tingkat kemampuan petani dalam mengelola hutan kemiri. Petani pengelola hutan kemiri yang berusia tua memiliki kemampuan yang lebih baik dibandingkan dengan petani yang berusia muda. Aspek umur ini sangat terkait dengan aspek karakteristik individu lainnya yang memiliki pengaruh terhadap tingkat kemampuan petani yaitu pengalaman mengelola hutan kemiri, dimana petani yang berusia tua adalah petani yang sudah lama berdomisili disekitar hutan kemiri dan sudah lama berinteraksi, mengelola dan memanfaatkan hutan kemiri, sehingga kemampuannya dalam mengelola hutan sudah menyatu dalam diri (terinternalisasi) dan menjadi bagian dari aktivitas hidupnya sehari-hari.

Aspek berikutnya yang mempengaruhi tingkat kemampuan petani adalah tingkat kebergantungan petani terhadap hutan kemiri. Walaupun, fakta penelitian memperlihatkan bahwa ketergantungan petani sekitar hutan terhadap hutan adalah rendah, dalam arti hasil hutan kemiri tidak lagi menjadi sumber pendapatan utama, namun berdasarkan hasil wawancara, petani masih membutuhkan hutan kemiri untuk menambah pendapatan rumah tangga atau menjadikan hasil hutan kemiri sebagai tabungan. Kebergantungan petani sekitar hutan Kabupaten Maros pada generasi petani saat ini lebih termanifestasi dalam bentuk keterikatan emosional mereka terhadap hutan kemiri sebagai akibat faktor psikologis, sosiologis, dan kultural.

\section{Faktor-Faktor yang Mempengaruhi Tingkat Motivasi Petani Sekitar Hutan Kemiri untuk Berpartisipasi}

Faktor-faktor yang mempengaruhi tingkat motivasi petani untuk berpartisipasi dalam mengelola hutan kemiri adalah:

Model Peningkatan Partisipasi Petani Sekitar Hutan dalam Pengelolaan ...... (Adi Riyanto Suprayitno et al.) 
1. Tingkat kemampuan petani; dan

2. Peluang yang tersedia

dengan persamaan struktural: $\mathrm{Y}_{2}=0,33 \mathrm{X}_{5}+0,55 \mathrm{Y}_{1}, \mathrm{R}^{2}=0,57$. Besarnya kontribusi kedua faktor tersebut secara bersama-sama terhadap partisipasi petani dalam pengelolaan hutan kemiri rakyat adalah sebesar 57\%.

\section{Tingkat kemampuan petani}

Tingkat kemampuan petani berpengaruh paling kuat terhadap tingkat motivasi petani untuk berpartisipasi dalam mengelola hutan kemiri, di mana aspek yang dominan mempengaruhi tingkat motivasi petani untuk berpartisipasi dalam pengelolaan hutan kemiri adalah kemampuan teknis. Kemampuan teknis petani sekitar hutan terbentuk melalui proses belajar informal secara turun temurun. Keberadaan hutan kemiri saat ini merupakan bukti nyata kemampuan teknis petani di bidang budidaya tanaman kemiri. Petani sekitar hutan yang secara turun temurun telah mengelola hutan dengan kemampuan yang dimiliki tersebut akan termotivasi untuk tetap berpartisipasi dalam mengelola hutan kemiri, karena yakin dan percaya diri telah memiliki modal pengetahuan dan keterampilan serta sikap yang positip sebagai prasyarat untuk mengelola hutan kemiri dengan baik. Walter dan Marks (1981) menyatakan bahwa kepemilikan kemampuan sebagai hasil proses learning by doing akan mendorong motivasi dan rasa percaya diri seseorang untuk melakukan pekerjaan tertentu.

Kemampuan sosial merupakan aspek kedua yang berpotensi mempengaruhi tingkat motivasi. Temuan ini menunjukkan bahwa kemampuan sosial petani dapat menjadi salah satu kekuatan pendorong atau kekuatan yang memotivasi petani untuk berpartisipasi dalam pengelolaan hutan kemiri. Dengan kemampuan sosial petani mampu membangun kepercayaan dan hubungan harmonis di antara mereka serta mampu mengatasi dan menyelesaikan masalah atau konflik yang timbul dalam lingkungan sosialnya.

Aspek kemampuan berikutnya yang berpotensi mempengaruhi tingkat motivasi petani untuk berpartisipasi dalam pengelolaan hutan kemiri adalah kemampuan manajerial dalam mengelola hutan kemiri. Lionberger dan Gwin (1982) menyatakan bahwa pada hakekatnya petani pedesaan telah memiliki kemampuan manajerial dalam menjalankan usahataninya, yang berbeda-beda antara satu petani dengan petani lainnya. Temuan ini menjelaskan bahwa kemampuan manajerial merupakan sumberdaya instrinsik petani yang dapat dimanfaatkan dan dikembangkan untuk kemajuan, perbaikan dan keberhasilan pengelolaan hutan kemiri.

\section{Ketersediaan peluang atau kesempatan}

Ketersedian kesempatan/peluang untuk berpartisipasi merupakan faktor kedua yang mempengaruhi tingkat motivasi petani untuk berpartisipasi dalam pengelolaan hutan kemiri, di mana dukungan pemerintah merupakan aspek yang paling dominan dalam mempengaruhi motivasi petani untuk berpartisipasi dalam pengelolaan hutan kemiri. Temuan ini memberikan dukungan pada paradigma pembangunan kehutananan saat ini yang bertumpu

pada pendekatan ekosistem yang dikenal dengan resources based management berbasis pada forest community based development. Namun demikian, pada saat ini dukungan pemerintah untuk memberikan wewenang dan berbagi tanggungjawab (share of responsibility) dalam mengelola hutan kemiri masih sangat terbatas.

Pengelolaan hutan yang diharapkan demokratis dan berkeadilan sebagaimana diamanatkan oleh UU No: 41/1999, pelaksanaannya masih terkesan ragu-ragu/belum 
sepenuh hati, sulit dan tidak taat azas sehingga belum terlihat secara nyata implementasinya di lokasi penelitian. Pada tataran implementasi, masih terdapat pelaksanaan kebijakan yang cenderung mengabaikan bahkan terkadang menegasikan hak-hak masyarakat lokal, dan kurang mempertimbangkan nilai-nilai sosiologis, historis, dan kultur serta pengetahuan masyarakat lokal. Terdapat kesan bahwa petani sekitar hutan hanya diberi tanggungjawab atas kelestarian, tanpa diikuti dengan perangkat wewenang untuk memutuskan pola kelestarian itu sendiri.

Kepastian pasar merupakan aspek berikutnya yang mempengaruhi tingkat motivasi petani sekitar hutan untuk berpartisipasi dalam pengelolaan hutan kemiri. Tujuan akhir dari suatu usahatani adalah, selain untuk pemenuhan kebutuhan rumah tangga, hasilnya dapat dijual atau memberikan keuntungan finansial. Pemasaran buah kemiri oleh petani sekitar hutan kemiri Kabupaten Maros, pada umumnya, tidak menemui banyak hambatan karena telah ada pihak yang siap menampung atau membeli produksi kapan saja petani menjualnya. Hal ini memberikan jaminan atas keberlangsungan finansial rumah tangga petani.

\section{E. Dampak Partisipasi Petani Sekitar Hutan Kemiri dalam Pengelolaan Hutan Kemiri terhadap Keberlanjutan Manfaat Hutan Kemiri}

Partisipasi petani dalam pengelolaan hutan kemiri memberikan dampak positip terhadap keberlanjutan manfaat hutan kemiri, dengan struktural: $Y_{4}=0,31 Y_{3}, R^{2}=0,10$.

Walaupun berdampak positif, partisipasi petani dalam pengelolaan hutan kemiri memberikan kontribusi yang relatif kecil terhadap keberlanjutan manfaat hutan kemiri, yaitu hanya sekitar 10\%, karena partisipasi petani sekitar hutan kemiri, pada saat ini, tidak ideal. Hal ini tercermin dari tahapan yang merefleksikan partisipasi tersebut. Terdapat hanya dua tahapan partisipasi yaitu tahapan dalam pelaksanaan pengelolaan hutan kemiri dan tahapan menikmati/ memanfaatkan hasil kegiatan pengelolaan hutan. Hal ini terjadi karena sejak diberlakukannya TGHK pada tahun 1984, akses petani untuk mengelola tanaman kemiri yang dimilikinya yang berada dalam kawasan hutan menjadi terbatas. Akses yang diperbolehkan hanya pada pemungutan buah kemiri. Petani sebagai pihak yang langsung merasakan manfaat hutan, akhirnya menilai bahwa manfaat hutan kemiri yang mereka rasakan sangat rendah, karena produktivitasnya sudah sangat rendah sebagai akibat komposisi tegakan kemiri yang didominasi $(79 \%)$ oleh tegakan berusia tua. Komposisi yang tidak ideal tersebut mengancam pula ekologis hutan dan kesejahteraan petani.

Tahapan pelaksanaan kegiatan pengelolaan hutan merupakan aspek paling dominan dalam meningkatkan keberlanjutan manfaat hutan. Namun kenyataannya, keterlibatan petani dalam melakukan kegiatan pengelolaan hutan sangat terbatas karena tidak adanya akses ke dalam hutan untuk mengelola tanaman kemirinya. Kalaupun ada yang melakukan, hal itu dilakukan secara sembunyi-sembunyi, dan dilakukan secara apa adanya atau sederhana. Tidak adanya kegiatan pengelolaan ini mengakibatkan tegakan kemiri yang ada didominasi oleh tegakan berusia tua yang produktivitasnya tidak dapat memenuhi kebutuhan rumah tangga petani.

Tahapan berikutnya yang berpotensi meningkatkan keberlanjutan manfaat hutan adalah partisipasi dalam memanfaatkan hasil kegiatan pengelolaan hutan. Partisipasi dalam memanfaatkan hutan kemiri tepat bila dikembangkan, tidak hanya dalam pemungutan buah dan kemudian dijual, namun juga dilakukan upaya diversifikasi terhadap biji kemiri berupa pengolahan buah kemiri menjadi bahan jadi seperti obat-obatan, minyak gosok yang

Model Peningkatan Partisipasi Petani Sekitar Hutan dalam Pengelolaan ...... (Adi Riyanto Suprayitno et al.) 
terangkum dalam skala usaha industri rumah tangga. Kegiatan ini, dapat lebih meningkatkan partisipasi petani dan meningkatkan nilai manfaat hutan bagi petani sekitar hutan.

\section{F. Model dan Strategi Peningkatan Partisipasi Petani Sekitar Hutan dalam Pengelolaan Hutan Kemiri Rakyat}

Model peningkatan partisipasi sekitar hutan dalam pengelolaan hutan kemiri rakyat (Gambar 3) dirancang dengan pendekatan input, process, output, dan outcome memperlihatkan bahwa tingkat partisipasi petani sekitar hutan dalam mengelola hutan kemiri dipengaruhi oleh tingkat kemampuan dan tingkat motivasi petani untuk berpartisipasi, di mana tingkat motivasi petani dipengaruhi oleh kemampuan petani dan adanya kesempatan/ peluang untuk berpartisipasi.

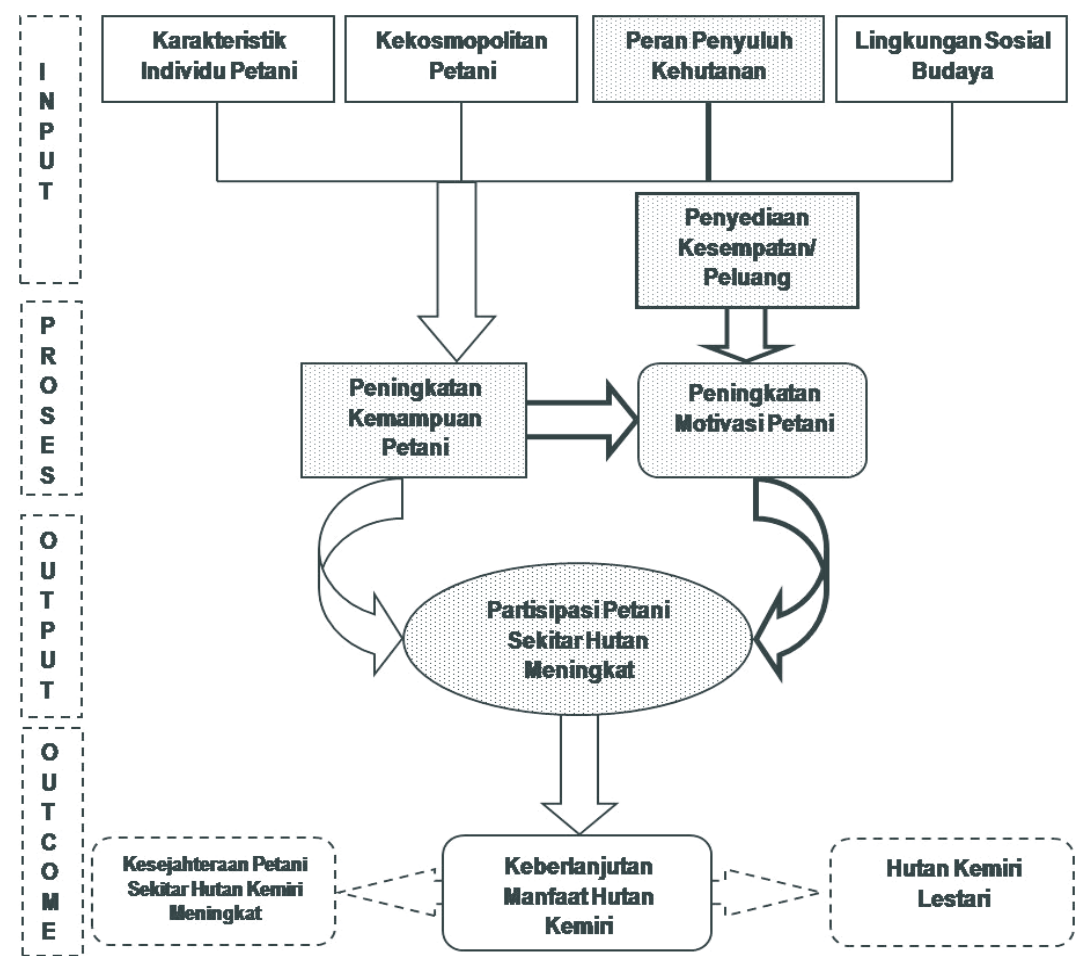

Gambar3. Model peningkatan partisipasi petani sekitar hutan dalam pengelolaan hutan kemiri rakyat

Figure 3. The Model for increasing farmers living around the forest participation in anaging community candlenutforest

Terlihat pula bahwa tingkat kemampuan petani dalam mengelola hutan kemiri dipengaruhi oleh karakteristik individu petani, tingkat kekosmopolitan petani, intensitas peran penyuluh kehutanan dan dukungan lingkungan sosial budaya. Partisipasi petani dalam pengelolaan hutan kemiri kondusif bagi terwujudnya keberlanjutan manfaat hutan. 
Demi mengimplementasikan secara lebih operasional, model di atas perlu dijabarkan ke dalam strategi peningkatan partisipasi petani sekitar hutan dalam pengelolaan hutan kemiri rakyat, yaitu (1) Strategi peningkatan motivasi petani sekitar hutan agar tetap berpartisipasi dalam mengelola hutan kemiri, dan (2) Strategi peningkatan kemampuan petani dalam pengelolaan hutan kemiri.

Kedua strategi bertujuan agar petani tetap mempertahankan dan meningkatkan partisipasinya. Untuk memotivasi petani sekitar hutan agar tetap berpartisipasi dalam mengelola hutan kemiri dan meningkatkan kemampuan petani dalam pengelolaan hutan kemiri sehingga partisipasi petani dapat meningkat, maka dirancang langkah-langkah strategis. Langkah-langkah strategis dirancang dengan mempertimbangkan besarnya pengaruh suatu aspek terhadap aspek lainnya. Jalur pengaruh yang lebih besar diprioritaskan untuk dilaksanakan terlebih dahulu.

1. Strategi peningkatan motivasi petani sekitar hutan agar tetap berpartisipasi dalam mengelola hutan kemiri.

Strategi pertama untuk meningkatkan partisipasi petani dalam pengelolaan hutan kemiri adalah meningkatkan motivasi petani sekitar hutan agar tetap berpartisipasi dalam mengelola hutan kemiri. Petani yang termotivasi akan penuh energi, terarah dan sekuat tenaga mempertahankan partisipasinya tersebut. Langkah-langkah strategis yang dilakukan adalah:

a. Menstimulir petani untuk memelihara, mengelola dan memanfaatkan hutan kemiri secara baik. Upaya ini perlu dikaitkan dengan keinginan petani untuk meningkatkan pendapatan dari produksi tanaman kemiri, dengan demikian perlu upaya peningkatan produktivitas tanaman kemiri melalui peremajaan tanaman kemiri dan pemeliharaan lanjutan.

b. Menyediakan kesempatan/peluang bagi petani sekitar hutan agar dapat terus terlibat dalam pengelolaan hutan kemiri. Upaya penyediaan kesempatan/peluang difokuskan dalam bentuk adanya dukungan pemerintah berupa pengakuan atau pemberian kewenangan/kepastian hak kelola terbatas kepada petani sekitar hutan untuk mengelola hutan kemiri.

c. Mendorong dan mengembangkan terciptanya industri rumah tangga. Perlu dilakukan upaya pengayaan atau diversifikasi produksi kemiri, sehingga penjualan produk kemiri tidak hanya dalam bentuk biji kemiri, namun dalam bentuk lainnya seperti minyak kemiri, bahan obat-obatan, shampo dan produk turunan lainnya sehingga memiliki nilai jual yang lebih tinggi

2. Strategi peningkatan kemampuan petani sekitar hutan dalam mengelola hutan kemiri.

Strategi kedua sebagai upaya meningkatkan partisipasi petani dalam pengelolaan hutan kemiri adalah meningkatkan kemampuan petani sekitar hutan dalam mengelola hutan kemiri. Kemampuan merupakan daya atau kesanggupan petani untuk melakukan kegiatan pengelolaan hutan. Dengan kemampuan yang sesuai dengan kaidah-kaidah pengelolaan hutan lestari maka keberlanjutan manfaat hutan akan dapat ditingkatkan. Langkah-langkah strategis yang dilakukan adalah:

a. Meningkatkan dan memperkuat kemampuan (pengetahuan, sikap positif, dan keterampilan) petani sekitar hutan dalam hal kemampuan teknis meliputi teknik persemaian, teknik pemeliharaan, teknik pemanenan dan pengolahan pasca panen; kemampuan manajerial meliputi perencanaan, evaluasi dan monitoring, dan pemasaran; dan kemampuan sosial meliputi kemampuan komunikasi, mediasi dan negosiasi.

b. Pengembangan dan peningkatan intensitas peran penyuluh kehutanan, sebagai faktor penting dalam peningkatan kemampuan petani, terutama peran fasilitator dan peran pendidik/edukator. Langkah strategis yang dilakukan adalah:

Model Peningkatan Partisipasi Petani Sekitar Hutan dalam Pengelolaan ...... (Adi Riyanto Suprayitno et al.) 
1) Perlu adanya kejelasan peran penyuluh dalam bentuk adanya kepastian tugas atau bidang yang disuluhkan. Kejelasan peran diperlukan karena selama ini penyuluh kehutanan bersifat polivalen, dengan kata lain harus melakukan kegiatan penyuluhan tidak saja bidang kehutanan tetapi juga bidang lainnya, sehingga penguasaan khusus dibidang kehutanan sangat terbatas.

2) Peningkatan kemampuan penyuluh kehutanan secara berkelanjutan agar kinerja penyuluh kehutanan semakin baik. Penyuluh yang ada memiliki keterbatasan pengetahuan di bidang kehutanan karena pada umumnya berlatar belakang ilmu teknis pertanian. Oleh karena itu peningkatan kemampuan penyuluh kehutanan diharapkan meliputi ilmu penyuluhan dan juga ilmu teknis kehutanan.

3) Menciptakan lingkungan kerja lembaga penyuluhan yang kondusif, meliputi

a) Lingkungan fisik berupa kelengkapan sarana dan fasilitas penyuluhan kehutanan perlu dimantapkan meliputi: bangunan, areal percontohan (demplot), mobilitas (sarana tranportasi), perlengkapan penyuluhan, dan biaya.
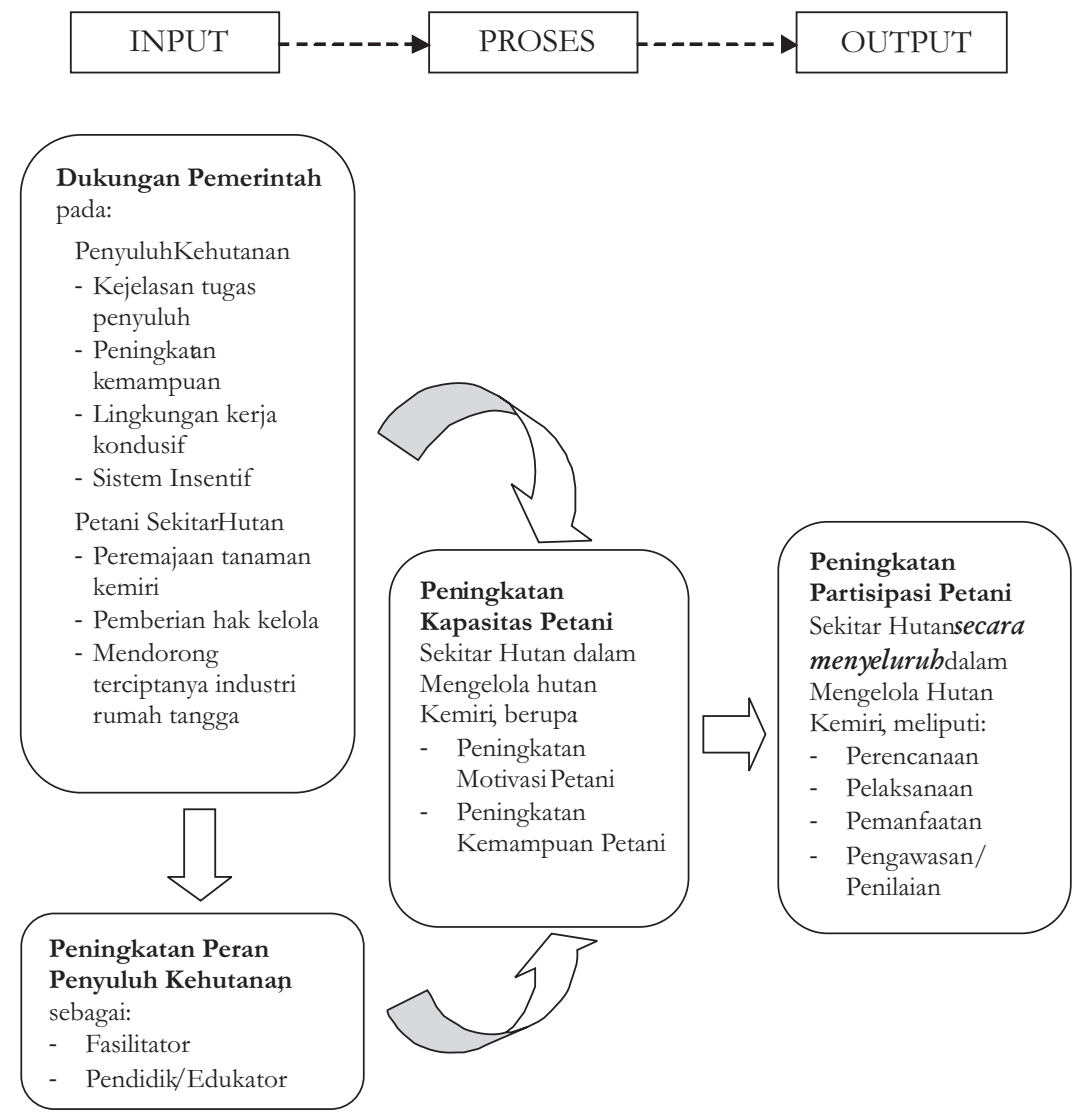

Gambar 4. Alur strategi peningkatan partisipasi petani sekitar hutan dalam mengelola hutan kemiri rakyat

Figure 4. Flowchart of strategy for increasing farmers living around the forest participation in managing community candlenut forest 
b) Lingkungan organisasi berupa kejelasan tugas dan karir penyuluh, perbaikan sistem kerja, iklim komunikasi yang suportif dengan cara meyakinkan para penyuluh, termasuk penyuluh kehutanan, akan kejelasan struktur organisasi dan eksistensi lembaga penyuluhan

c) Lingkungan manusia berupa memperluas kesempatan bagi penyuluh kehutanan untuk bersikap kreatif dan eksperimental, membangun sikap empati dan responsif diantara pimpinan dan penyuluh kehutanan serta diantara penyuluh.

Skema alur strategi peningkatan partisipasi petani dalam mengelola hutan kemiri rakyat disajikan pada Gambar 4 dengan pendekatan masukan (input), proses (process), dan keluaran (output).

\section{KESIMPULAN DAN SARAN}

\section{A. Kesimpulan}

1. Tingkat partisipasi petani sekitar hutan dalam pengelolaan hutan kemiri tergolong rendah dan bersifat parsial atau tidak ideal, hanya dua tahapan yang merefleksikan partisipasi petani dalam pengelolaan hutan kemiri rakyat yaitu: a) partisipasi dalam melaksanakan kegiatan pengelolaan hutan kemiri; dan b) partisipasi dalam menikmati atau memanfaatkan hasil hutan.

Faktor-faktor yang berpengaruh terhadap rendahnya tingkat partisipasi petani adalah:

a. Belum optimalnya tingkat kemampuan petani dalam mengelola dan memanfaatkan hutan, yang ditandai dengan rendahnya aspek kemampuan manajerial petani. Belum optimalnya kemampuan petani sangat dipengaruhi oleh rendahnya intensitas peran penyuluh kehutanan, baik peran sebagai fasilitator maupun sebagai pendidik.

b. Tingkat motivasi petani sekitar hutan untuk berpartisipasi dalam pengelolaan hutan kemiri yang tergolong sedang. Faktor yang mempengaruhi sedangnya tingkat motivasi petani adalah tingkat kemampuan manajerial petani yang tergolong rendah dan rendahnya ketersediaan kesempatan/peluang terutama dukungan pemerintah.

2. Partisipasi memberikan dampak positif pada keberlanjutan manfaat hutan kemiri, namun, manfaat hutan tersebut dirasakan rendah oleh petani. Rendahnya keberlanjutan manfaat hutan yang dirasakan petani dipengaruhi oleh rendahnya partisipasi petani.

3. Model peningkatan partisipasi adalah peningkatan partisipasi petani melalui (a) dukungan motivasi petani dalam hal motivasi untuk meningkatkan pendapatan, motivasi untuk mendapat pengakuan atas kemampuan mengelola hutan dan motivasi untuk melestarikan hutan; dan (b) dukungan kemampuan petani dalam hal kemampuan teknis, kemampuan manajerial dan kemampuan sosial.

4. Model peningkatan partisipasi petani sekitar hutan dijabarkan ke dalam dua strategi yaitu:

a. Strategi peningkatan motivasi petani sekitar hutan. Langkah strategis yang dapat dilakukan adalah:

1) Meningkatkan produktivitas tanaman kemiri melalui peremajaan tanaman kemiri dan pemeliharaan lanjutan.

2) Menyediakan peluang kepada petani untuk mengelola hutan dalam bentuk adanya kepastian kewenangan atau pemberian hak kelola kepada petani.

Model Peningkatan Partisipasi Petani Sekitar Hutan dalam Pengelolaan ...... (Adi Riyanto Suprayitno et al.) 
3) Mendorong dan mengembangkan terciptanya industri rumah tangga. Perlu dilakukan upaya pengayaan atau diversifikasi produksi kemiri, sehingga penjualan produk kemiri tidak hanya dalam bentuk biji kemiri, namun dalam bentuk lainnya sehingga memiliki nilai jual yang lebih tinggi

b. Strategi peningkatan kemampuan petani sekitar hutan dalam mengelola hutan kemiri. Upaya yang dilakukan adalah:

1) Meningkatkan dan memperkuat kemampuan teknis petani sekitar hutan meliputi teknik persemaian, teknik pemeliharaan, teknik pemanenan dan pengolahan pasca panen; kemampuan manajerial meliputi perencanaan, evaluasi dan monitoring, dan pemasaran; dan kemampuan sosial meliputi kemampuan komunikasi, mediasi dan negosiasi.

2) Mengembangkan dan meningkatkan intensitas peran penyuluh kehutanan terutama peran fasilitator dan peran pendidik, sebagai faktor penting yang berpengaruh dalam peningkatan kemampuan petani langkah strategis yang dapat dilakukan adalah:

a) Perlu adanya kejelasan peran penyuluh dalam bentuk adanya kepastian tugas atau bidang yang disuluhkan.

b) Peningkatan kemampuan penyuluh kehutanan secara berkelanjutan agar kinerja penyuluh kehutanan semakin baik. Penyuluh yang ada memiliki keterbatasan pengetahuan di bidang kehutanan karena pada umumnya berlatar belakang ilmu teknis pertanian. Oleh karena itu peningkatan kemampuan penyuluh kehutanan diharapkan meliputi ilmu penyuluhan dan ilmu teknis kehutanan

c) Menciptakan lingkungan kerja lembaga penyuluhan yang kondusif. Lingkungan fisik berupa kelengkapan sarana dan fasilitas penyuluhan kehutanan. Lingkungan organisasi berupa perbaikan sistem kerja, iklim komunikasi yang suportif, meyakinkan penyuluh kehutanan, akan kejelasan tugas dan karir penyuluh, kejelasan struktur organisasi dan keberlanjutan eksistensi lembaga penyuluhan.

\section{B. Saran}

1. Dalam rangka meningkatkan kinerja partisipasi petani sekitar hutan kemiri Kabupaten Maros, maka pemerintah baik pusat maupun daerah perlu lebih memahami kemampuan dan motivasi berpartisipasi petani dalam mengelola hutan kemiri serta faktor-faktor yang mempengaruhinya.

2. Mengingat partisipasi petani sekitar hutan kemiri masih bersifat parsial, terbatas pada tahapan melaksanakan dan memanfaatkan hasil, maka dinilai perlu untuk mengembangkan dan meningkatkan partisipasi petani pada dua tahapan lainnya yaitu tahapan merencanakan serta tahapan mengawasi dan menilai hasil kegiatan pengelolaan hutan kemiri.

3. Mengingat bahwa tingkat motivasi petani sekitar hutan untuk berpartisipasi dalam pengelolaan hutan kemiri dipengaruhi oleh tingkat kemampuan petani dan dukungan kesempatan atau peluang, maka perlu dilakukan upaya:

a. Peningkatan kemampuan petani sekitar hutan kemiri terutama pada aspek kemampuan manajerial karena aspek ini berdasarkan temuan penelitian masih rendah. 
b. Memberikan kesempatan/peluang kepada petani sekitar hutan untuk tetap terlibat dalam pengelolaan hutan kemiri dalam bentuk adanya dukungan kebijakan atau peraturan yang memberikan kepastian kewenangan atau hak untuk mengelola hutan.

4. Mengingat peran penyuluh kehutanan sangat penting dalam meningkatkan kemampuan petani sekitar hutan dalam mengelola hutan kemiri, maka diperlukan upaya peningkatan intensitas peran penyuluh kehutanan.

5. Mengingat bahwa kearifan lokal merupakan sumberdaya internal masyarakat yang telah melahirkan praktek pengelolaan hutan kemiri dan telah terbukti dengan baik membangun hutan kemiri, maka dinilai perlu untuk menjaga dan melestarikan kearifan lokal tersebut dimana pemanfaatannya perlu penyesuaian diri dan ditransformasikan sesuai dengan perkembangan pembangunan kehutanan saat ini.

\section{DAFTAR PUSTAKA}

Awang SA. 2003. Politik Kehutanan Masyarakat. Yogyakarta: Center for Critical Social Studies \& Kreasi Wacana Yogyakarta.

Hanafi A. 1986. Memasyarakatkan Ide-Ide Baru. Surabaya: Usaha Nasional.

Lionberger HF, Gwin PH. 1982. Communication Strategies: A Guide for Agricultural Change Agents. Illinois: The Interstate Printers \& Publishers.

Sudjana D. 2000. Strategi Pembelajaran. Bandung: Falah Production.

Van Den Ban AW, Hawkis HS. 1999. Penyuluhan Pertanian. Yogyakarta: Kanisius.

Walter GA, Marks SE. 1981. Experiental Learning And Change: Theory, Design and Practice. Canada: John Wiley \& Sons, Inc.

Model Peningkatan Partisipasi Petani Sekitar Hutan dalam Pengelolaan ...... (Adi Riyanto Suprayitno et al.) 